\title{
ORAL PENICILLIN IN THE NEWBORN
}

BY

B. LEVIN, M.D., Ph.D., and CATHERINE A. NEILL, M.D., M.R.C.P. (From the Mothers' Hospital and the Queen Elizabeth Hospital for Children, London)

This investigation was initiated to determine the optimal dose of oral penicillin required to give a satisfactory penicillin blood level in infants under a month old and to compare the relative efficacy of penicillin and sulphathiazole paste in the treatment of minor skin lesions in infants during the neonatal period. The obvious advantages of penicillin over other drugs are counterbalanced by the discomfort of intramuscular injections and the possible danger of infection in the injection site. Oral penicillin is clearly preferable to intramuscular injection provided adequate blood levels are attained.

\section{Previoes Investigntions}

When this investigation was commenced early in 1947, two reports had appeared (Henderson and McAdam, 1946, and Buchanan, 1946) on oral penicillin in infants. Both showed that adequate and sustained blood penicillin levels could be obtained in this way. Since then a number of other favourable reports have appeared (Markowitz and Kuttner, 1947 ; Hoffman, Hofer, and Gordon, 1948; Lapin, 1948; Suchett-Kaye and Latter, 1947). Early investigations had shown (Florey, M. E., and Florey, H. W., 1943; Abraham, Chain, Fletcher, Gardner, Heatley, Jennings, and Florey, 1941; Rammelkamp and Keefer, 1943) that with adults a proportion of the penicillin given by mouth was absorbed, but that this was small. Later investigations have shown that with very high doses of penicillin given orally, a reasonable blood level can be maintained in adults. McDermott et al. (1945) stated that about 20 per cent. of the penicillin given orally to adults was excreted in the urine, whereas following intramuscular penicillin about 60 to 70 per cent. was excreted. They conclude that since about one-third of the oral penicillin is absorbed, in order to reach comparable blood levels the oral dose must be at least three times the intramuscular dose, and, to cover those cases in which the absorption is less than 33 per cent., it is better to give five times as much.

Seeberg et al. (1946) have similarly shown that in cats urinary excretion is five times greater after intramuscular than oral penicillin with equivalent amount. They further showed that the duodenum and small intestine were the areas of greatest absorption, and the colon the area of greatest destruction of penicillin.

Two explanations have been suggested for the lower blood penicillin levels with oral therapy. (1) Gastric acidity inactivates or destroys part of the penicillin.

(2) Absorption occurs mainly in the duodenum and small intestine; what is not absorbed is destroyed by penicillinase-producing organisms in the large intestine, little or none being excreted in the faeces.

A third possibility has been advanced by Free et al. (1945) that after oral penicillin some is destroyed or stored in the liver.

If the first explanation were correct, protection from gastric acidity should increase the amount of penicillin absorbed. A number of investigators have reported on the effects in adults of giving oral penicillin with antacids, buffers, oils, and in capsules, with conflicting results. Seager (1946) obtained higher levels with antacids than with tap-water. György et al. (1945) showed that higher levels could be obtained with trisodium citrate buffered penicillin than with aqueous penicillin. On the other hand, McDermott et al. (1946) found that results with penicillin in plain water were as good as penicillin given with various antacids. Further, in achlorhydric patients the absorption of oral penicillin was little or no better than in normal subjects. Oberst et al. (1946) and Free et al. (1945) also concluded that simple aqueous penicillin gave as good results as penicillin with antacids. In children Cohlan et al. (1948) obtained higher levels with trisodium citrate buffered penicillin than with unbuffered penicillin, whereas in infants buffering made no difference to the levels. They found that when penicillin was incubated in vitro with the gastric juice of infants there was little destruction of penicillin, whereas almost complete destruction occurred when the gastric juice of children was substituted. They ascribed this difference to the greater acidity of the latter. It has been noted, however, that higher levels are obtained when penicillin is given before meals. Reisman et al. (1947) found no difference between penicillin in saline and buffered penicillin in children, but noted that levels were best when penicillin was given half an hour before or three hours after a meal. Markowits and Kuttner (1947) gave oral penicillin to children between six and fourteen years, half an hour before breakfast, just before breakfast, and immediately after meals. The blood levels were highest in the first series, oply slightly lower in the second, and very low and irregular in the third. This confirmed previously reported observations. 


\section{Present Investigations; Penicilin Blood Levels}

Finst Series. This comprised forty-two cases and seventy-nine blood levels were determined. The dose given was $120,000-160,000$ units per twenty-four hours.

In order to be certain of attaining adequate levels of penicillin in the blood, a massive dose was first used: 20,000 units were given three- or four-hourly, depending on the number of feeds, giving a total dosage of 120,000 or 160,000 units per twenty-four hours. The dosage per lb. consequently varied widely with the birth weight and was between 13,000 and 40,000 units. The ordinary sodium penicillin tablets, not containing citrate, were used, dissolved immediately before use, and given in a teaspoon of water just before the feed. Occasionally, if the penicillin was refused, the solution was mixed with milk, and given before the feed.

For the estimation of the blood penicillin level, blood was withdrawn from the heel with the usual precautions one hour after, and again three or four hours after the dose had been given, depending on the time of feed. In all cases the estimation was performed after the infant had been on penicillin for twenty-four to forty-eight hours, when blood levels would be expected to be higher than those following a single dose, since in many cases there is an appreciable amount of penicillin in the blood three or four hours after a dose. The method of estimation was similar to that of Fleming (1947), using a strain of Staph. aureus which has been in continuous use for this purpose. It is sensitive to a penicillin concentration of 0.031 units per $\mathrm{ml}$. Serial dilutions of the serum to be estimated were made in small 2 in. by $\frac{3}{8}$ in. test tubes, using a glucose serum broth containing phenol red as indicator. To $5 \mathrm{ml}$. of this medium was added $20 \mathrm{c} . \mathrm{mm}$. of an eight-hourculture of the test organism. Where sufficient serum was available, a second series of intermediate dilutions was also done. A control series, containing known dilutions of

TABuE 1

PENICILLIN LEVELS (DOSE: 20,000 UNITS EVERY THREE OR FOUR HOURS) IN THE NEWBORN

\begin{tabular}{|c|c|c|c|c|c|c|c|c|c|c|c|}
\hline \multicolumn{8}{|c|}{ Penicillin Blood Level (units per ml.) } & \multirow{2}{*}{$\begin{array}{c}\text { Weighting } \\
0\end{array}$} & \multirow{2}{*}{$\begin{array}{c}\text { One Hour } \\
0 \\
\end{array}$} & \multirow{2}{*}{$\begin{array}{c}\text { Three Hours } \\
0\end{array}$} & \multirow{2}{*}{$\begin{array}{c}\text { Four Hours } \\
2 \\
\end{array}$} \\
\hline 0 & $\cdots$ & $\cdots$ & $\cdots$ & $\because$ & $\cdots$ & $\cdots$ & $\cdots$ & & & & \\
\hline 0.031 & $\cdots$ & $\cdots$ & $\cdots$ & $\cdots$ & $\because$ & $\cdots$ & $\cdots$ & 1 & 0 & 0 & 3 \\
\hline 0.046 & $\cdots$ & $\cdots$ & $\cdots$ & $\cdots$ & $\cdots$ & $\cdots$ & $\cdots$ & $1 \cdot 5$ & 0 & $\mathbf{0}$ & $i$ \\
\hline 0.062 & $\cdots$ & $\cdots$ & $\cdots$ & $\cdots$ & $\cdots$ & $\cdots$ & $\cdots$ & $2 \cdot 0$ & 3 & 1 & 3 \\
\hline 0.093 & $\cdots$ & $\cdots$ & $\cdots$ & $\cdots$ & $\cdots$ & $\cdots$ & $\cdots$ & $2 \cdot 5$ & $\mathbf{0}$ & $\mathbf{0}$ & 0 \\
\hline $0 \cdot 125$ & $\cdots$ & $\cdots$ & $\cdots$ & $\therefore$ & $\cdots$ & $\cdots$ & $\cdots$ & $3 \cdot 0$ & 3 & 2 & 1 \\
\hline $0 \cdot 19$ & $\cdots$ & $\cdots$ & $\cdots$ & $\cdots$ & $\cdots$ & $\cdots$ & $\cdots$ & $3 \cdot 5$ & 2 & 1 & 1 \\
\hline 0.25 & $\cdots$ & . & $\cdots$ & $\cdots$ & $\cdots$ & $\cdots$ & $\cdots$ & $4 \cdot 0$ & 2 & 1 & 2 \\
\hline 0.375 & $\ldots$ & $\cdots$ & $\cdots$ & . & $\cdots$ & . & $\cdots$ & $4 \cdot 5$ & 3 & 4 & 1 \\
\hline $0 \cdot 50$ & $\cdots$ & $\cdots$ & $\cdots$ & $\cdots$ & . & $\cdots$ & $\cdots$ & $5 \cdot 0$ & 10 & 4 & 5 \\
\hline $0 \cdot 75$ & $\cdots$ & $\cdots$ & $\cdots$ & $\cdots$ & $\cdots$ & . & $\cdots$ & $5 \cdot 5$ & 1 & 0 & 2 \\
\hline $1 \cdot 0$ & $\cdots$ & $\cdots$ & $\cdots$ & $\cdots$ & $\cdots$ & . & $\cdots$ & $6 \cdot 0$ & 5 & 2 & 2 \\
\hline $1 \cdot 5$ & $\cdots$ & $\cdots$ & $\cdots$ & $\cdots$ & $\cdots$ & $\cdots$ & $\cdots$ & $6 \cdot 5$ & 4 & 0 & 1 \\
\hline $2 \cdot 0$ & $\cdots$ & $\cdots$ & . & $\cdots$ & . & $\cdots$ & $\cdots$ & $7 \cdot 0$ & 2 & 3 & 0 \\
\hline $2 \cdot 5$ & $\cdots$ & $\cdots$ & . & $\cdots$ & $\cdots$ & $\cdots$ & $\cdots$ & $7 \cdot 5$ & 1 & 0 & 0 \\
\hline 3.0 & $\cdots$ & . & $\cdots$ & $\cdots$ & $\ldots$ & $\cdots$ & $\cdots$ & $8 \cdot 0$ & 0 & 0 & 0 \\
\hline $4 \cdot 0$ & $\ldots$ & . & $\cdots$ & $\cdots$ & $\cdots$ & $\cdots$ & $\cdots$ & $9 \cdot 0$ & 1 & 0 & 0 \\
\hline Numbe & er 0 & estii & tions & $\cdots$ & $\cdots$ & . & $\cdots$ & & 37 & 18 & 24 \\
\hline $\begin{array}{l}\text { Arithm } \\
\text { Goome }\end{array}$ & $\begin{array}{l}\text { netic } \\
\text { etric }\end{array}$ & ver & (uni & per & ) & $\cdots$ & & & $\begin{array}{l}0.81 \\
0.50\end{array}$ & $\begin{array}{l}0.68 \\
0.45\end{array}$ & $\begin{array}{l}0.37 \\
0 \cdot 19\end{array}$ \\
\hline
\end{tabular}


penicillin, was also set up at the same time. No non-specific inhibition of the test organism was found in any of several specimens of serum taken for this purpose. The number of times a zero penicillin level was found may also be taken as a control. It must be remembered that this method is subject to relatively large inaccuracies, especially in the latter end of a series of tubes where an error of one tube means a difference of one or more units per $\mathrm{ml}$.

The blood levels obtained, and their frequency distribution, are shown in table 1 .

At the end of one hour and of three hours, no blood levels were below 0.062 units per $\mathrm{ml}$., whereas at the end of four hours, six out of twenty-four levels were below 0.062 units, and of these two were zero readings.

The most frequent level attained at the end of the first hour was 0.5 units. There is a slight shift to lower levels at the end of three hours, and at the end of four hours this shift is very marked. In all three groups there is an occasional high blood level, which gives an unduly high result to the arithmetic mean. The actual method of assay of penicillin is one of doubling dilutions; this is in the nature of a geometrical progression, and may lead to large errors in the higher ranges. Hoffman et al. (1948) have pointed out that the geometric mean, for this reason, gives a better picture of the average blood level attained than the arithmetic mean. In the second column a linear weighting is given for each penicillin level. The arithmetic mean is found for these weightings, and the mean thus obtained is converted back into units per $\mathrm{ml}$.
These results are in general agreement with those reported by other workers.

Second Series. This comprised twenty-nine cases and fifty-seven blood levels were determined. The dose given was 5,000 units per lb. birth weight in twenty-four hours.

Having shown that the very large dose of 120,000 160,000 units in twenty-four hours will give high blood levels, the attempt was made to determine whether adequate levels could be obtained with smaller doses. It was therefore decided to give 5,000 units per $\mathrm{lb}$. in twenty-four hours divided into three- or four-hourly doses as required. Since in adults, 1,000 units per lb. in twenty-four hours by intramuscular injection gives adequate blood level, it might have been expected that an oral dosage of 5,000 units per lb. in twenty-four hours would give adequate błood levels in infants. The total dose per twenty-four hours was made up, and $1 \mathrm{ml}$. given either three- or four-hourly, before feeds, as in the first series. Blood was removed for estimation, one hour, three hours, and four hours afterwards as before. The results are shown in table 2.

It will be seen that compared with the higher dose the blood levels are more erratic. At the end of one hour, about one-third were below 0.062 and three-quarters of the levels were at or below 0.125 units per ml.; whereas in the first series the corresponding figures are none below 0.062 , and about one-fifth at or below 0.125 units per $\mathrm{ml}$. At the end of three hours in the second series about one-quarter were below 0.062 units, and over two-thirds at or below 0.125 units; whereas in the

TABLE 2

PENICILLIN LEVELS (DOSE: 5,000 UNITS PER LB. OVER TWENTY-FOUR HOURS) IN THE NEWBORN

\begin{tabular}{|c|c|c|c|c|c|c|c|c|c|c|c|}
\hline \multicolumn{8}{|c|}{ Penicillin Blood Level (units per ml.) } & \multirow{2}{*}{$\frac{\text { Weighting }}{0}$} & \multirow{2}{*}{$\frac{\text { One Hour }}{0}$} & \multirow{2}{*}{$\frac{\text { Three Hours }}{1}$} & \multirow{2}{*}{$\frac{\text { Four Hours }}{2}$} \\
\hline $\mathbf{0}$ & $\cdots$ & $\cdots$ & $\cdots$ & $\cdots$ & $\cdots$ & $\cdots$ & $\cdots$ & & & & \\
\hline 0.031 & $\cdots$ & $\cdots$ & $\cdots$ & $\cdots$ & $\cdots$ & $\cdots$ & $\cdots$ & $1 \cdot 0$ & 5 & 0 & 3 \\
\hline $0 \cdot 046$ & $\cdots$ & $\cdots$ & $\cdots$ & $\cdots$ & $\cdots$ & $\cdots$ & $\cdots$ & $1 \cdot 5$ & 5 & 2 & 3 \\
\hline 0.062 & $\cdots$ & . & . & $\cdots$ & $\cdots$ & $\cdots$ & $\cdots$ & $2 \cdot 0$ & 4 & 1 & 1 \\
\hline 0.093 & . & . & $\cdots$ & $\cdots$ & $\cdots$ & $\cdots$ & $\cdots$ & $2 \cdot 5$ & 3 & 2 & 1 \\
\hline $0 \cdot 125$ & . & . & $\cdots$ & $\cdots$ & $\cdots$ & $\cdots$ & $\cdots$ & $3 \cdot 0$ & 5 & 3 & 1 \\
\hline $0 \cdot 19$ & $\cdots$ & . & $\cdots$ & $\cdots$ & $\cdots$ & $\ldots$ & $\ldots$ & $3 \cdot 5$ & 1 & 0 & 1 \\
\hline $0 \cdot 25$ & $\cdots$ & - & $\cdots$ & $\cdots$ & $\cdots$ & $\cdots$ & ..' & $4 \cdot 0$ & 0 & 2 & 3 \\
\hline 0.375 & $\cdots$ & $\cdots$ & $\cdots$ & $\cdots$ & $\cdots$ & $\cdots$ & $\cdots$ & $4 \cdot 5$ & 2 & 1 & 0 \\
\hline 0.50 & $\cdots$ & $\cdots$ & $\cdots$ & $\cdots$ & $\cdots$ & $\cdots$ & $\cdots$ & $5 \cdot 0$ & 4 & 1 & 0 \\
\hline \multicolumn{4}{|c|}{ Number of estimations } & $\cdots$ & $\cdots$ & $\cdots$ & $\cdots$ & & 29 & 13 & 15 \\
\hline \multicolumn{6}{|c|}{$\begin{array}{l}\text { Arithmetic average (units per ml.). } \\
\text { Geometric mean (units per ml.) .. }\end{array}$} & $\cdots$ & $\cdots$ & & $\begin{array}{l}0 \cdot 154 \\
0 \cdot 10\end{array}$ & $\begin{array}{l}0 \cdot 161 \\
0 \cdot 122\end{array}$ & $\begin{array}{l}0 \cdot 097 \\
0 \cdot 064\end{array}$ \\
\hline
\end{tabular}


first series the corresponding figures are none below 0.062 , and one-sixth at or below 0.125 units.

Third Series. This series of older children comprised eight cases and sixteen blood levels were determined.

In a small series the blood penicillin levels were estimated on children between the ages of one and ten years. A dose of approximately 5,000 units per lb. in twenty-four hours was given orally ten minutes before a meal. The results are shown in table 3.

Comparison of Intramescalar and Oral Penicilis

The results indicate that 120,000 to 160,000 units in twenty-four hours in divided doses will give a very adequate bacteriostatic level in infants up to one month. A comparison between the oral administration and intramuscular injection is shown in fige 1.

Penicillin levels following a single injection (of 20,000 units) of penicillin in a four-day-old infant weighing $73 \mathrm{lb}$. have been plotted. The curve for oral penicillin $(20,000$ units every three or four

TABIE 3

PENICILLIN LEVELS (DOSE: 5,000 UNITS PER LB.) IN CHILDREN AGED 1 TO 10 YEARS

\begin{tabular}{|c|c|c|c|c|c|c|c|c|c|}
\hline \multicolumn{2}{|c|}{ Penicillin } & \multicolumn{5}{|c|}{ Blood Level (units per ml.) } & \multirow{2}{*}{$\frac{\text { Weighting }}{0}$} & \multirow{2}{*}{$\frac{\text { One Hour }}{2}$} & \multirow{2}{*}{$\frac{\text { Three Hours }}{7}$} \\
\hline $\mathbf{0}$ & $\cdots$ & $\cdots$ & $\cdots$ & $\cdots$ & $\cdots$ & $\cdots$ & & & \\
\hline 0.031 & $\cdots$ & $\cdots$ & . & $\cdots$ & . & $\cdots$ & $1 \cdot 0$ & $\mathbf{0}$ & 0 \\
\hline 0.046 & $\cdots$ & $\cdots$ & $\cdots$ & - & . & $\cdots$ & $1 \cdot 5$ & 2 & 16 \\
\hline 0.062 & $\cdots$ & $\cdots$ & $\cdots$ & $\cdots$ & $\cdots$ & $\cdots$ & $2 \cdot 0$ & 1 & 一 \\
\hline 0.093 & $\cdots$ & $\cdots$ & $\cdots$ & $\cdots$ & $\cdots$ & $\cdots$ & $2 \cdot 5$ & 2 & - \\
\hline $0 \cdot 125$ & $\cdots$ & $\cdots$ & $\cdots$ & $\cdots$ & . & $\cdots$ & $3 \cdot 0$ & 1 & - \\
\hline \multicolumn{4}{|c|}{ Number of estimations } & $\cdots$ & $\cdots$ & $\cdots$ & & 8 & 8 \\
\hline \multicolumn{6}{|c|}{$\begin{array}{l}\text { Arithmetic average (units per ml.) .. } \\
\text { Geometric mean (units per ml.) }\end{array}$} & $\cdots$ & & $\begin{array}{l}0.058 \\
0.055\end{array}$ & $\begin{array}{l}0 \cdot 006 \\
0 \cdot 006\end{array}$ \\
\hline
\end{tabular}

The blood levels in this series are appreciably lower than those obtained with the comparable dose in infants under one month.

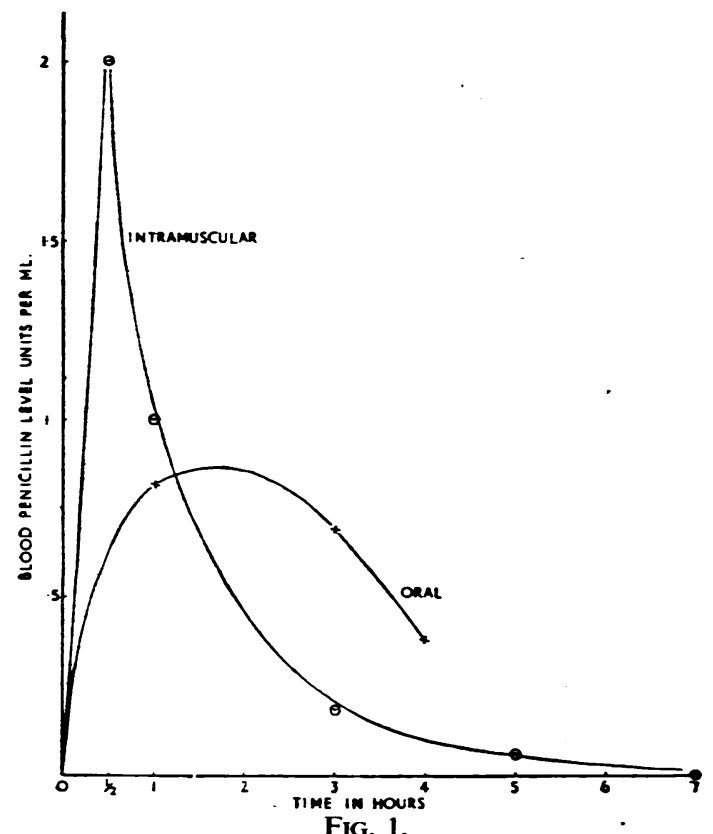

hours) is constructed from the data of table 1 . The graph shows clearly that there is a higher initial level reached in the first hour after intramuscular dose, but this falls off much more rapidly than after oral penicillin, so that for the next three hours the latter levels are higher. Whether it is better to have a very high initial blood level followed by lower blood levels, or to have, as in oral penicillin, a moderately high blood level throughout the whole period, is not yet determined. It should be noted that the scatter in the blood levels after oral penicillin is such that in a proportion of cases there will be a zero blood level after four hours. This constitutes a serious argument against oral penicillin, unless this is checked by an estimation performed at the end of three or four hours, according to the intervals at which the penicillin is given.

The lower dose of 5,000 units per lb. in twentyfour hours will also frequently give a bacteriostatic level. A comparison between blood levels obtained three hours after intramuscular injection using a dose of 1,000 units per lb. in twenty-four hours and oral penicillin of five times the amount is given in table 4. The figures for blood levels after intramuscular penicillin are those given by Bodian (1946). The arithmetic and geometric means have been calculated from his results. This shows the average levels obtained are higher in this small series with oral penicillin; 18 per cent. showed zero levels with intramuscular penicillin as against $7 \cdot 7$ per cent. 
with oral. When the levels obtained at the end of four hours after oral penicillin are included the blood levels obtained are still higher than three hours after 1,000 units given intramuscularly. It should be noted that Bodian's series refers to infants under a year, the exact age not being stated. one 'average' and one 'low' level it was included in the low group; where one 'average' and one 'high' level were obtained, the result was included in the high group. No case had both a 'high' and a 'low' blood level. In the first series, of a total of forty-two cases, thirteen blood levels were 'low,'

TABLE 4

COMPARISON OF INTRAMUSCULAR AND ORAL PENICILLIN

\begin{tabular}{|c|c|c|c|c|c|c|c|}
\hline \multirow{2}{*}{\multicolumn{3}{|c|}{$\begin{array}{c}\text { Intramuscular } \\
\text { (1,000 units per lb. in } 24 \text { hours) } \\
\text { enicillin blood level three hours after } \\
\text { dose }\end{array}$}} & \multicolumn{3}{|c|}{$\begin{array}{c}\text { Oral } \\
\text { (5,000 units per } 1 \mathrm{lb} \text {. in } 24 \text { hours) }\end{array}$} & \multicolumn{2}{|c|}{$\begin{array}{c}\text { Oral } \\
(5,000 \text { units per lb. in } 24 \mathrm{hrs} .)\end{array}$} \\
\hline & & & \multicolumn{3}{|c|}{$\begin{array}{l}\begin{array}{l}\text { Penicillin blood level three hours after } \\
\text { dose }\end{array} \\
\end{array}$} & \multicolumn{2}{|c|}{$\begin{array}{l}\text { Penicillin blood level four } \\
\text { hours after dose }\end{array}$} \\
\hline Units per ml. & Levels & Per cent. & Units per ml. & Levels & Per cent. & Levels & Per cent. \\
\hline $\begin{array}{l}0 \\
\begin{array}{l}0.02 \\
0 \cdot 04 \\
0 \cdot 08 \\
0 \cdot 16\end{array} \\
\end{array}$ & $\begin{array}{r}11 \\
21 \\
15 \\
9 \\
5\end{array}$ & $\begin{array}{r}18 \\
34 \\
25 \\
15 \\
8\end{array}$ & $\begin{array}{l}0.0 \\
0 \cdot 031 \\
0 \cdot 046 \\
0.062 \\
0.093 \\
0 \cdot 125 \\
0 \cdot 19 \\
0 \cdot 25 \\
0 \cdot 375 \\
0 \cdot 50\end{array}$ & $\begin{array}{l}1 \\
0 \\
2 \\
1 \\
2 \\
3 \\
0 \\
2 \\
1 \\
1\end{array}$ & $\begin{array}{r}7 \cdot 7 \\
0 \cdot 0 \\
15 \cdot 4 \\
7 \cdot 7 \\
15 \cdot 4 \\
23 \cdot 0 \\
0 \cdot 0 \\
15 \cdot 4 \\
7 \cdot 7 \\
7 \cdot 7\end{array}$ & $\begin{array}{l}2 \\
3 \\
3 \\
1 \\
1 \\
1 \\
1 \\
3 \\
0 \\
0\end{array}$ & $\begin{array}{r}13 \cdot 3 \\
20.0 \\
20.0 \\
6.7 \\
6.7 \\
6.7 \\
6.7 \\
20.0\end{array}$ \\
\hline \multicolumn{2}{|c|}{ No. of estimations } & 61 & \multicolumn{3}{|c|}{13} & \multicolumn{2}{|c|}{15} \\
\hline \multicolumn{3}{|c|}{$\begin{array}{ll}\begin{array}{c}\text { Arithmetic average } \\
\text { (units per ml.) }\end{array} & 0.042 \\
\begin{array}{c}\text { Geometric mean } \\
\text { (units per ml.) }\end{array} & 0.032\end{array}$} & \multicolumn{3}{|c|}{$0 \cdot 161$} & \multicolumn{2}{|c|}{$\begin{array}{l}0.097 \\
0.064\end{array}$} \\
\hline
\end{tabular}

* Bodian, 1946.

Factors Influencing Blood Levels

It has been generally accepted that oral penicillin in infants gives higher blood levels than comparable amounts in older children. The results obtained in this investigation support this. Henderson and McAdam (1946) point out that whereas in adults it is necessary to give orally five times the intramuscular dose in order to obtain comparable blood levels, in infants an oral dose of 10,000 units will give a bacteriostatic level for a longer time than the same dose given intramuscularly although a higher initial dose is reached with the latter. A similar result is shown in fig. 1 where an oral dose of 20,000 units is compared with the same amount given intramuscularly. Again, an oral dose of 5,000 units per $\mathrm{lb}$. in twenty-four hours gives better levels than 1,000 units per lb. in twenty-four hours given intramuscularly.

Various reasons have been advanced to account for this discrepancy between infants and older children. In an attempt to determine whether our results would throw any further light on the problem of factors influencing blood levels, we divided our cases into those showing 'high', 'average', and 'low' blood levels. The division was purely arbitrary and is shown in fig. 2 . Where a case had fifteen were 'average,' and fourteen were ' high.' In the second series of a total of twenty-nine cases, twelve blood levels were 'low,' nine were 'average', and eight were 'high.'

The results were then analysed for the clinical factors of age (table 5), fluid intake, prematurity, and dosage to see if there were any significant and constant differences between the three groups.

In infants under forty-eight hours most give high penicillin blood levels; in the infants under seven days there is a slight preponderance in the high level group; in infants between eight and fourteen days there is a much greater preponderance in the low level group. The number of infants over fourteen days old is small but results indicate an approximately equal distribution in all three groups.

The fluid intake was ascertained on the same day that the penicillin was started and the day before the penicillin level was estimated. Table 6 shows the number of results falling into each group.

Of the infants eight days of age or over, five had a fluid intake of less than $2 \mathrm{oz}$. per lb. birth weight in twenty-four hours, while twenty-seven had a fluid intake of $2 \mathrm{oz}$. or over (see table 6a).

These results show a tendency for low fluid intake to be associated with high blood levels and vice versa. 


\section{SERIES I}

SERIES III

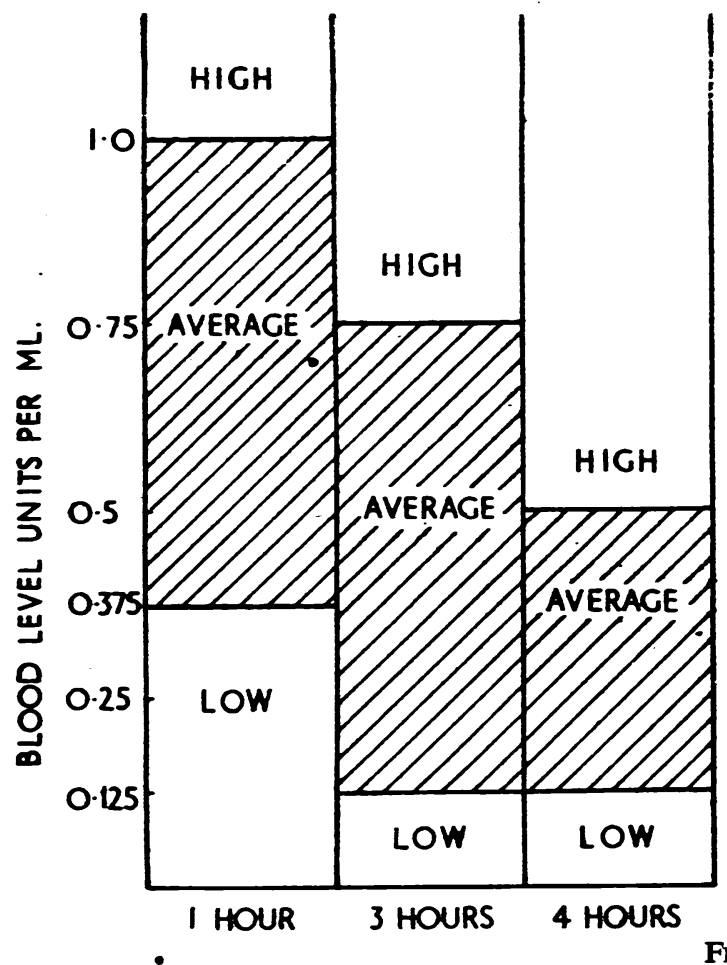

Fig: 2.

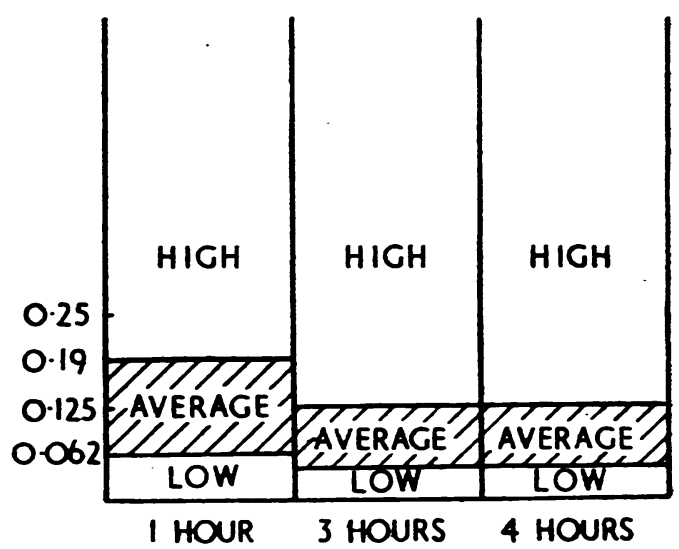

Penicillin blood levels: division into high, average and low groups

TABRE 5

RELATION OF AGE TO PENICILIN BLOOD LEVELS IN THE NEWBORN

\begin{tabular}{|c|c|c|c|c|c|}
\hline \multirow{2}{*}{\multicolumn{3}{|c|}{$\begin{array}{c}\text { Age } \\
\text { (When penicillin level was estimated) }\end{array}$}} & \multicolumn{3}{|c|}{ Penicillin Blood Level Group } \\
\hline & & & \multirow{2}{*}{$\begin{array}{c}\begin{array}{c}\text { High } \\
\text { (No. of cases) }\end{array} \\
7\end{array}$} & \multirow{2}{*}{$\begin{array}{c}\begin{array}{c}\text { Average } \\
\text { No. of cases) }\end{array} \\
1\end{array}$} & \multirow{2}{*}{$\begin{array}{c}\begin{array}{c}\text { Low } \\
\text { (No. of cases) }\end{array} \\
1\end{array}$} \\
\hline 48 hours or less & $\ldots$ & $\ldots$ & & & \\
\hline 0.7 days (includin & first group) & .. & 15 & 14 & 10 \\
\hline 8-14 days & $\ldots$ & $\ldots$ & 3 & 8 & 12 \\
\hline Over 14 days. & $\ldots$ & $\ldots$ & 4 & 2 & 3 \\
\hline
\end{tabular}

TABLE 6

RELATION OF FLUID INTAKE TO PENICILLIN BLOOD LEVEL

\begin{tabular}{l|c|c|c|c|c}
\hline \multirow{2}{*}{ Fluid Intake } & \multicolumn{2}{|c|}{ Penicillin Blood Level Group } & \multicolumn{1}{c}{} \\
\cline { 2 - 6 } & $\begin{array}{c}\text { High } \\
\text { (No. of cases) }\end{array}$ & $\begin{array}{c}\text { Average } \\
\text { (No. of cases) }\end{array}$ & $\begin{array}{c}\text { Low } \\
\text { (No. of cases) }\end{array}$ & $\begin{array}{c}\text { Mean Age } \\
\text { (in days) }\end{array}$ & $\begin{array}{c}\text { Range } \\
\text { (in days) }\end{array}$ \\
\hline Less than 1 oz per lb. in 24 hours & 8 & 2 & 0 & 1.6 & $1-2$ \\
\hline $1-2$ oz per lb. in 24 hours & 8 & 6 & 7 & 5.0 & $1-16$ \\
\hline Over 2 oz. per lb. in 24 hours & 6 & 16 & 18 & 18.0 & $5-30$ \\
\hline
\end{tabular}


TABLE 6 a

FLUID INTAKE AND PENICILLIN LEVEL IN INFANTS OVER 7 DAYS OLD

\begin{tabular}{c|c|c|c}
\hline \multirow{2}{*}{ Fluid Intake } & \multicolumn{2}{c}{ Penicillin Blood Level } \\
\cline { 2 - 4 } & High & Average & Low \\
\hline Intake under 2 oz. per lb. & 3 & 1 & 1 \\
\hline Intake 2 oz. per lb. or over & 4 & 10 & 13 \\
\hline
\end{tabular}

In table 7 is shown the relation of prematurity to blood levels. Although the number of premature infants included was small there was a slight preponderance of results in the high level group. This was true in both series, and did not seem to be due to high dosage per lb. Amongst full-term infants the numbers in all three groups were approximately the same.

TABLE 7

RELATION OF PREMATURITY TO PENICILLIN BLOOD LEVEL

\begin{tabular}{lc|ccc}
\hline & & \multicolumn{2}{c}{ Penicillin Blood Level } \\
\cline { 3 - 5 } & & High & Average & Low \\
\hline Premature infants & $\cdots$ & 5 & 7 & 2 \\
\hline Full term infants .. &. & 17 & 17 & 23 \\
\hline
\end{tabular}

In the first series the dose per lb. per twenty-four hours varied between 13,000 and 40,000 units (see table 8).

The low levels encountered with doses of 20,000 units per lb. in twenty-four hours occurred in infants of eight days or over and with a fluid intake of $2 \mathrm{oz}$. per $\mathbf{l b}$. birth weight in twenty-four hours or more.

Other factors considered included the simultaneous use of sulphonamides, the previous use of intramuscular penicillin, and the presence of gastrointestinal upsets. There was no evidence in our series that any of them had any effect on the blood levels. In six cases where intramuscular penicillin had previously been given it had been stopped at least thirty-six hours before the oral blood level was estimated. There were no gastro-intestinal upsets. Oedema was present in only three infants. Of these, two had high blood levels and one average. Jaundice was described as deeper than normal in two cases, both with ' high' levels.

Varintion with Age in Penicillin Blood Levels In discussing the variation of penicillin blood levels with age two chief points of interest arise: (1) Why are better and more consistent blood levels attained with oral penicillin in infants than in adults, and (2) at what age do the results become less satisfactory. Husson (1947) in recording the blood levels following the administration of oral penicillin to infants between the ages of one week and five months, has discussed some possible reasons for the higher blood levels in infants compared with older children and adults. The second point was not investigated, as our cases are confined to the neonatal period. As for the first point, the following reasons have been postulated. (1) The lower gastric acidity in infants might mean that less penicillin was destroyed. We have done no gastric analyses, but our results show a definite tendency for blood levels to be higher in the first week of life than later; according to Miller (1941), gastric acidity in infants is high on the first day, falls to a low level on the eighth to tenth day, and slowly rises thereafter. In our series, therefore, higher blood levels are obtained when gastric acidity is high; this is the reverse of the expected effect. This point is of increased interest because penicillin tablets for oral use containing sodium citrate are now being marketed; we have, since this series of cases was collected, seen infants who develop cedema while on such 'citrated' tablets, and feel that such 'buffering' may prove troublesome as well as apparently unnecessary.

TABUE 8

RELATION OF DOSE PER LB. BIRTH WEIGHT IN TWENTY-FOUR HOURS AND BLOOD LEVELS (SERIES I)

Penicillin Blood Level Group

\begin{tabular}{|c|c|c|c|c|c|c|c|}
\hline \multirow{2}{*}{\multicolumn{5}{|c|}{ Dose per lb. per 24 hours }} & \multirow[b]{2}{*}{ High } & \multirow{2}{*}{ Average } & \multirow{2}{*}{ Low } \\
\hline & & & & & & & \\
\hline Below 15,000 $\ldots$ & $\cdots$ & $\cdots$ & $\cdots$ & $\cdots$ & 2 & 2 & 2 \\
\hline 15 -under 20,000 & $\cdots$ & $\cdots$ & $\cdots$ & $\cdots$ & 3 & 5 & 6 \\
\hline 20 -under 25,000 & .. & .. & . & $\ldots$ & 5 & 4 & 3 \\
\hline 25 -under 30,000 & $\ldots$ & . & $\ldots$ & $\ldots$ & 2 & 2 & 2 \\
\hline 30,000 or over & . & . & . & $\cdots$ & 2 & 2 & 0 \\
\hline
\end{tabular}


Duodenal absorption may be more rapid and effective in infants. We have no evidence on this point.

Penicillinase-producing organisms in the intestine are probably less frequent in the first day or two of life. Our series does suggest that in the very early days of life (i.e. during the first forty-eight hours) when the large intestine is relatively sterile, higher blood levels are attained. The question of age in our series, however, is very closely correlated with a low fluid intake, as shown in table 6. Variation in fluid intake might account for the differences between infants under forty-eight hours and those after the first week, but obviously could not account for the differences between infants and older children (tables 2 and 4).

Poor renal function in infants with consequent diminished excretion has been suggested as a possible factor. The level of penicillin in the blood after intramuscular injection appears to be reduced as rapidly by renal excretion in the infant as it is in the adult; in other words, the blood level curve obtained is essentially similar. This suggests that renal function is not an important factor. It is interesting to note that in our series there seemed to be little or no relation between oedema and blood level variation.

Liver function has not to our knowledge been shown to bear any relation to penicillin blood levels in infants or adults, but this point might be worth investigating further in the newborn.

On our small series, therefore, we consider that one important factor causing differences in penicillin blood level during the neonatal period is fluid intake. Increased absorption from the intestine, possibly due to the relative absence of penicillinaseproducing organisms in the first month of life, may account for higher blood levels in the newborn compared with older children and adults.

\section{Indications for Treatment}

The cases treated fell into three main groups, (1) skin sepsis of varying degrees of severity, (2) upper respiratory infection including otitis media, and, (3) prophylactic treatment for atelectasis. There was no definite correlation between the rate of healing of lesions and the penicillin blood level, but it should be noted that no cases of severe generalized infection were treated by this method. Treatment with oral penicillin was found satisfactory for the rather limited sphere in which it was used.

No definite toxic effects were observed. Only one baby vomited whilst on penicillin, and he had been vomiting slightly before treatment was started. One infant developed a rash, but he was also on sulphadiazine and the rash cleared on stopping the latter. It may be mentioned that the nursing staff

TABLE 9

COMPARISON OF SULPHATHIAZOLE PASTE AND ORAL PENICILLIN FOR SKIN LESIONS

Results
Sulphathiazole Paste
Oral Per cent. Penicillin Per cent.

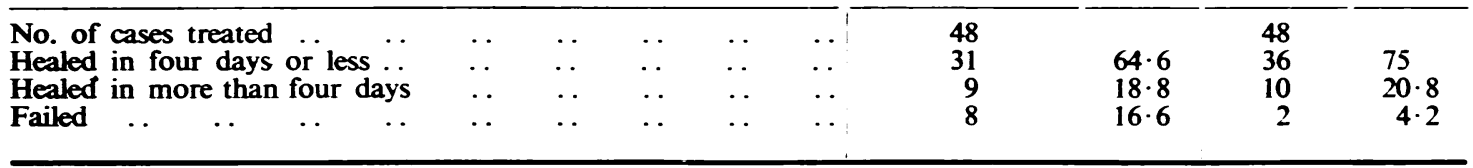

TABLE 10

BACTERIOLOGY OF SKIN LESIONS

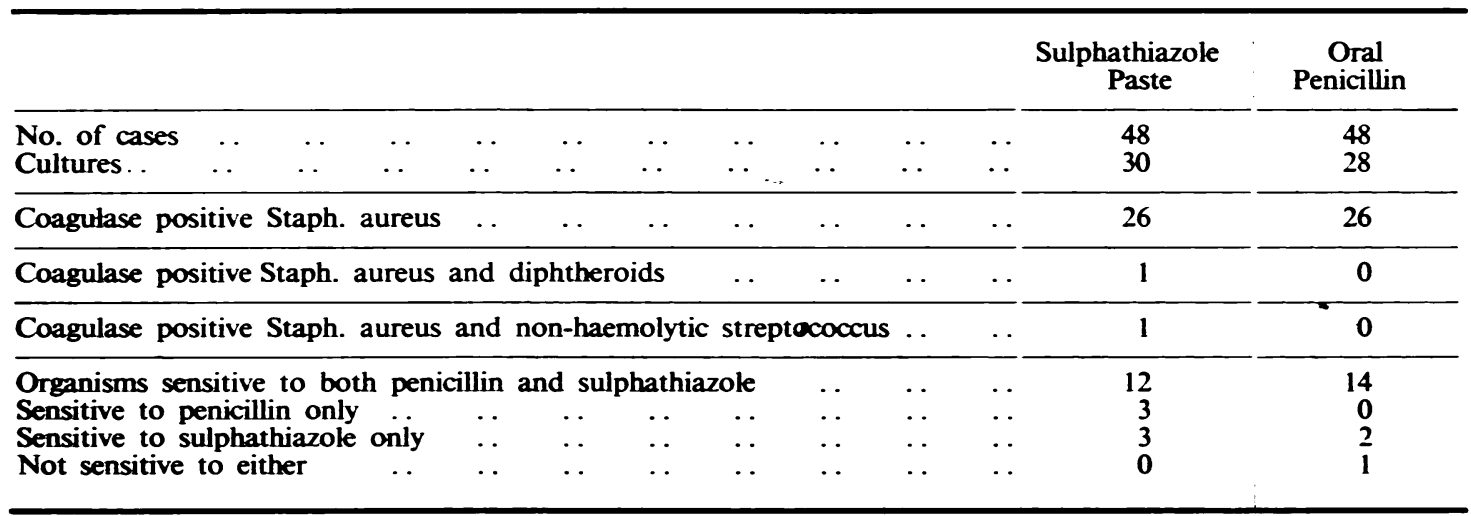


have an impression that some infants take their feed less satisfactorily when on penicillin. The drug should not be used in the presence of diarrhoea or vomiting and we would not ourselves use it in very acutely ill infants, as it may be possible that absorption is less good in such cases.

Although 5,000 units per lb. in twenty-four hours gave adequate levels in a majority of cases, there is a sufficiently wide scatter to make one chary of advising this as a routine dose. In infants under a week old, in our series, occasional low levels were encountered unless a dose as high as 20,000 units per lb. in twenty-four hours was used, while in infants over a week, there were sometimes low levels below 30,000 units' per lb. We would suggest, therefore, that a dose of at least 20,000 units per lb. in twenty-four hours, given before feeds, should be used as a routine.

\section{Comparison of Sulphathiazole Paste and Oral Penicillin}

The types of skin lesions treated were paronychia, boils, pustules, and mildly infected forceps wounds. A total of ninety-six cases were treated, divided equally into those treated with penicillin and sulphathiazole paste ( 5 per cent.) respectively. Cases of intertrigo or sore buttocks which were not infected were not included. These cases were chosen in the following way. All infants developing skin infection in alternate wards (housed in separate blocks) were treated routinely either with sulphathiazole paste or oral penicillin. (See table 9.)

A culture was possible in a total of fifty-eight cases, from which a pure growth of coagulase positive Staph. aureus was obtained in fifty-two cases; in two further cases either diphtheroids or nonhaemolytic streptococcus were isolated in addition to Staph. aureus. In four instances, coagulase negative Staph. albus only was isolated. The sensitivity to penicillin and sulphathiazole was determined in thirty-five instances. The results obtained are given in table 10.

The results show a slight superiority in favour of penicillin. Though the difference is small, and might be attributed to chance, an impression has been gathered from experience with both forms of treatment that although sulphathiazole paste is adequate for cases where there are only a few pustules, where lesions are numerous this treatment is unsatisfactory.

\section{Summary}

1. The blood levels following (a) a high dose of 20,000 units penicillin three- or four-hourly, (b) the lower dose of 5,000 units per lb. in twenty-four hours have been ascertained in a group of infants under one month of age.

2. It is shown that, whilst the lower dose frequently gives an adequate bacteriostatic level, the higher dose is preferable since an adequate level is reached in almost all cases.

3. We would suggest a routine dose of 20,000 units per lb. in twenty-four hours.

4. The factors influencing the higher blood levels in infants as against older children are discussed. It has been shown that higher blood levels are associated with decreased fluid intake, and that the younger the infant, the higher, in general, the blood level. No completely acceptable explanation of the difference has been found, but it is thought that either better absorption from the small intestine, or less destruction in the colon may be a much greater factor than has been supposed.

5. In minor skin lesions in infants penicillin orally appears slightly superior to sulphathiazole paste applied locally.

Our thanks are due to Dr. H. M. M. Mackay for many suggestions and much helpful advice and criticism. We should also like to thank Dr. S. Yudkin, Dr. Lucille Morgan, and Dr. P. Watts for their co-operation and help.

\section{REFERENCES}

Abraham, E. P., Chain, E., Fletcher, C. M., Gardner, A. D., Heatley, N. G., Jennings, M. A., and Florey, H. W. (1941). Lancet, 2, 177.

Bodian, M. (1946). Arch. Dis. Childh., 21, 13.

Buchanan, J. L. (1946). Lancet, 2560.

Cohlan, S. Q., Lewis, J. M., and Seligmann, E. (1948). Amer. J. Dis. Child., 75, 19.

Fleming, A., May, J. R., and Voureka, A. E. (1947). Brit. med.J., 1, 627.

Florey, M. E., and Florey, H. W. (1943). Lancet, 1, 387.

Free, A. H., Parker, R. F., and Biro, B. E. (1945). Science, 102, 666.

György, $P_{t}$, Vandergrift, H. N., Elias, W., Colio, L. G., Barry, F. M., and Pilcher, J. D. (1945). J. Amer. med. Ass., 127, 639.

Henderson, J. L., and McAdam, I.- W. J. (1946). Lancet, 1, 922.

Hoffman, W. S., Hofer, J. W., and Gordon, H. (1948). J. Paediat., 32, 1.

Husson, G. S. J. (1947). J. Pediat., 31, 651.

Lapin, J. H. (1948). J. Paediat., 32, 119.

Markowitz, M., and Kuttner, A. G. (1947). J. Paediat., 31, 195 .

McDermott, W., Bunn, P. A., Benoit, M., DuBois, R., and Reynolds, M. E. (1946). Science, 103, 359.

Miller, R. A. (1941). Arch. Dis. Childh. 16, 22.

Oberst, F. W., Foter, M. J., and Nielsen, F. A. (1946). Cincinnati J. Medicine, 27, 696.

Rammelkamp, C. H., and Keefer, C. S. (1943). J. clin., Invest., $22,425$.

Reisman, H. A., Goldfarb, A. A., and Molloy, M. (1947). Amer. J. Dis. Child., 74, 19.

Seager, L. D. (1946). Ibid., 103, 353.

Seeberg, V. P., Illg, P. L., and Brown, D. J. and Wickert, M. L. (1946). J. Amer. pharm. Assoc., 35, 280.

Smith, C. A. (1945). Physiology of the Newborn Infant, 1st Ed. Springfield, Illinois.

Suchett-Kaye, A. I., and Latter, R. B. (1947). Brit. med. J., $2,953$. 